\title{
DETERMINANTS OF HOUSEHOLD FINANCIAL VULNERABILITY: EVIDENCE FROM SELECTED EU COUNTRIES
}

\author{
Nikola Šubová1, Ladislav Mura², Ján Buleca ${ }^{3}$
}

\footnotetext{
1 Technical University of Košice, Faculty of Economics, Department of Finance, Slovakia, ORCID: 0000-0003-0158-2332, nikola.subova@tuke.sk;

2 Pan-European University, Faculty of Economics and Business, Department of International Entrepreneurship, Slovakia, ORCID: 0000-0002-2453-8740, ladislav.mura@gmail.com;

3 Technical University of Košice, Faculty of Economics, Department of Finance, Slovakia, ORCID: 0000-0002-6613-2167, jan.buleca@tuke.sk (corresponding author).
}

\begin{abstract}
Household debt has been increasing in the last decades, and it poses a threat not only to the financial stability of households but is a precursor of the economic and financial crisis. A downturn caused by the coronavirus pandemic is expected to deepening inequalities, mainly due to the inability of households to repay existing debts or finance basic living needs. Understanding the determinants of household indebtedness and financial vulnerability is crucial for policymakers who process measures to prevent increasing household indebtedness. This paper investigates the determinants of household financial vulnerability in euro area countries using the Household Finance and Consumption Survey micro-dataset collected by the European Central Bank. The quantitative approach was applied using ordinary least square and quantile estimation procedures. The difference between OLS and quantile estimations showed the appropriateness of using the quantile regression approach. Performance analysis proved that only the number of elderly and the value of wealth and existence of mortgage interest tax relief statistically significant affects the level of vulnerability in all three waves. While the increasing number of elderly and greater value of household wealth lowers the vulnerability, the effect of mortgage interest tax relief differs across individual waves. All other used factors are essential and statistically significant for the financial vulnerability of households as well, but the importance and significance could differ across the distribution and individual waves. The effect of financial assets, education, and employment were found to be negative in all observations of all waves. On the other hand, the number of children and the value of households' real assets is associated with increased financial vulnerability indicators.
\end{abstract}

Keywords: Household, vulnerability, indebtedness, regression analysis.

JEL Classification: C21, D14, G51.

APA Style Citation: Šubová, N., Mura, L., \& Buleca, J. (2021). Determinants of Household Financial Vulnerability: Evidence from Selected EU countries. E\&M Economics and Management, 24(3), 186-207. https://doi.org/10.15240/tul/001/2021-3-011

\section{Introduction}

The financial crisis of $2007 / 2008$, known as the global financial crisis, caused by a combination of an asset price bubble in the real estate sector and a credit bubble leading to excessive leverage, highlighted the importance of the household sector for financial stability of the whole economy. Easy to get a loan and the belief that the house prices would appreciate encouraged more borrowers to get into debt. American households and financial institutions became deeply indebted. At the end of 2007, American households' total loans and debt securities relative to the GDP was $98.55 \%$ (International Monetary Fund, 2020). Mortgage defaults caused by the financial crisis affected 
financial stability also in European countries. The household sector can influence the economy mainly due to its size and position on the financial markets, but on the other hand, the economic situation of households is also affected by various social, economic, and political changes. High financial vulnerability and high level of household debt are precursors of crisis that result in a growing interest in analysing the financial situation, risk profile, and stability of households.

Financial vulnerability is the status of financial instability, in which households are exposed to various financial risks and shocks (Lee \& Sabri, 2017). Financial vulnerability is also represented as the poverty of assets or lower wealth accumulation, leading to the inability to cope with unexpected situations such as unemployment, illness, or higher housing-related expenses (Abid \& Shafiai, 2018; Noerhidajati et al., 2021).

Vulnerable households do not pose a risk only to the economy but also to themselves due to several reasons. Lack of financial stability, inability to finance consumption and a higher level of indebtedness affect future well-being and psychological features of household members as well. In connection with ensuring financial stability and lowering the vulnerability of households, personal financial management is considered the most significant problem. Managing resources and gaining control over the financial situation allow individuals to assess the financial situation of the entire household (Treanor, 2016; Lee \& Sabri, 2017).

The most common indicator of household financial vulnerability is household debt used to calculate various vulnerability measurements (debt-to-asset ratio, debt-to-income ratio, debt service-to-income ratio). Household debt in the euro area evaluated by the gross debt-to-income ratio has fluctuated in the last decade. It reached the highest level in 2010 (98.79\%). From this year, the euro area household debt has decreased by $5.11 \%$. The highest value of the gross debt-toincome ratio was reported in Denmark $(214.16 \%)$ and Cyprus (134.18\%), while the lowest value of this indicator was recorded in Romania (24.00\%), Hungary (33.31\%), and Latvia (32.19\%) in 2019. The gross debt-to-income ratio of the Slovak households has risen from $30.87 \%$ in 2007 to $69.64 \%$ in 2019 (Eurostat, 2019).

The massive increase of household debt over the last decades could be partially attributed to the introduction of the economic and monetary union that caused a convergence of countries' interest rates joined in the Eurozone. The common currency Euro eliminated the exchange rate risk and made loans more available (Yildirim, 2015; Nölke, 2016). Nowadays, the threat of household indebtedness increases as the economic crisis caused by the coronavirus is expected to deepen inequalities due to the inability to repay existing debt and to finance basic living needs. Two years before the pandemic hit, one of three EU households could not handle unexpected expenses, while savings of many households were equivalent to just a few weeks of basic consumptions (Demertizs et al., 2020). As the crisis of last year has led to substantial reductions in earnings, it has further reduced the ability of households to finance unexpected expenditures (Midões \& Seré, 2020).

Moreover, one of the main tools for reducing financial vulnerability is a sufficient level of liquid financial assets, especially savings that can be used as an income replacement. Compared to U.S. households, European households have fewer financial assets, and it also contributes to the importance of vulnerability analysis (Eurostat, 2021; Statista, 2021). From a practical point of view, household financial stability is essential for developed countries as it represents one of the threats to economic recovery from the economic crisis. To alert households to risk factors and take preventive measures suitable for different households, it is necessary to know what has the most significant impact on vulnerability. Therefore, there is a question about which factors deepen the financial vulnerability the most and whether it changes at various levels of indebtedness.

The submitted paper aims to identify sociodemographic determinants of indebtedness raising the household financial vulnerability in selected EU countries. The paper also analyses how the implemented macroprudential policies translate into different levels of household financial vulnerability indicator. The study results can help national and international authorities determine which household characteristics and household heads need to be supported to reduce financial vulnerability. Furthermore, the conducted study helps to answer the following research questions:

- What are the key demographic and social factors affecting the level of households' financial vulnerability? 
- What effect do different implemented macroprudential policies have on the level of households' financial vulnerability?

\section{Background}

Households are vulnerable due to several reasons. The most critical factors affecting financial stability and vulnerability are sociodemographic, economic characteristics (income, solvency, age, the level of education, household size, marital status, financial behaviour, and solvency), and personal characteristics (risk tolerance, financial literacy) of each member in the household (Rahim, 2011; Catherine et al., 2016; Daud et al., 2018; Walugemde et al., 2019). Households' sociodemographic characteristics such as age, household size, number of children, gender, and education drive vulnerability forces. To mitigate the financial vulnerability of households and its consequences, the number of studies analysing the determinants of vulnerability has increased. In addition, considerable attention is put to financial vulnerability using various econometric methods and vulnerability measurements.

Household members acquire financial management skills at an early age. They are surrounded by different social groups and occasionally try to imitate the consumption habits and living standards of their neighbours, colleagues, and people around them even they have lower income. Households that cannot cover their consumption are more indebted, but they are more likely to be unable to pay off their debts and expose themselves to financial instability. Increasing income inequality triggers debt-financed consumption, leads to debt accumulation, and increases households' financial vulnerability (Wildauer, 2016).

Young people usually set up their households; they are driven by materialism and borrow early. It leads to debt accumulation and threats to financial stability. The effect of age on debt is negative because older people usually spend less and do not cover their consumption by debt. It is confirmed in the studies using simple regression and multilevel mixed-effect linear regression (Danziger et al., 1982; Haq et al., 2018). The financial vulnerability of households decreases with the increasing age (Grejcz \& Żółkiewski, 2017; Azzopardi et al., 2019).

Contrary to this, another cross-country analysis of households' financial vulnerability and its determinants based on the estimation of a linear regression equation showed that young people are more susceptible to potential vulnerability (Daud et al., 2018). However, a higher debt of households with young members is not as alarming as the indebtedness of the elderly that Modigliani's Life Cycle Income Hypothesis describes. According to this hypothesis, the income of individuals increases over the life cycle until it reaches the maximum in midlife. It is associated with more significant savings (Modigliani, 1986). On the other hand, the income of older people usually decreases. Without effective pension systems, insurance plans, and support systems, they cannot repay debts that pose a risk not only for their financial stability but also for the stability of financial institutions.

Household size and the number of children also have a noticeable effect on the demand for loans, but it can be seen indirectly through living expenses. Analysing microfinance and household's access to credit by probit modelling in the study of Togba (2012) showed that households with more members have higher expenses, and therefore there is a higher probability of applying for a loan to fund their consumption. A study using a quantile regression approach to determine the characteristics of households' saving rate explains that children are usually referred to as indicators for household dependency. As a result, households with more children spend more and save less (Hua \& Erreygers, 2019). A study determining the characteristics of household over-indebtedness showed that the financial stability of households depends on the gender of the household head, and the financial behaviour of men and women can differ. Female-headed households are usually more indebted, explained by the lower age of retirement, unstable and lower average income, and responsibility for bearing children. Although debt-to-income ratios are usually much more for male-headed households, females with loans are more likely to be over-indebted and unable to repay the existing loan (Ntsalaze \& Ikhide, 2016). On the other hand, women are usually more risk-averse therefore prefer investments in safer, lower-yield assets that lower their financial vulnerability (Killewald et al., 2018).

Another socio-demographic factor essential for the financial stability of households is the level of education. Higher levels of 
education and financial literacy lower financial vulnerability because it improves financial knowledge and skills. It is associated with a better understanding of the different financial products and has decreased financial vulnerability. Financial literacy and self-control influence the level of unsecured debt offered by non-banking institutions, and it is also reflected in financial vulnerability indicators (Sri et al., 2020). Households with the lower educational attainment of each member are more indebted and tend to fail in debt repayment (Azzopardi et al., 2019).

On the other hand, the households with a higher level of education have better financial management and lower financial vulnerability and financial fragility (Noerhidajati et al., 2021; Yusof et al., 2015). Another study analysing measurements and determinants of household financial vulnerability by the fractional logit estimation technique explains that educational levels predict the ability of a household to manage financial resources. Educational attainment is also essential in the savings process. Subjects with lower educational attainment tend to save less. On the other hand, more significant savings of individuals with higher education help overcome unexpected economic situations and maintain financial stability (Brounen et al., 2016).

A study by Sachin et al. (2018) explains that financial vulnerability is influenced by financial determinants such as assets, wealth, and income. An asset is negatively associated with the level of financial vulnerability while it is a quick source of income mainly in unexpected situations, but only a specific type of assets leads to the lower financial vulnerability. For example, savings are quickly monetisable assets, and therefore they could be used as an income replacement. On the other hand, the effect of buildings and land assets ownership is not confirmed while they are high illiquid, and it is hard to use these assets immediately in an unexpected situation. It is explained in the study using descriptive research in analysing spending patterns and their effects on financial vulnerability. Financial vulnerability is driven by low wealth as well. Wealth accumulation helps build emergency funds that can help make a stressful economic situation easier to handle.

Basic microeconomic theory suggests that higher income decreases financial vulnerability, but research papers' results can be twofold.
Firstly, it is in line with the study suggesting that the income level is negatively associated with household vulnerability while higher income allows individuals to absorb adverse shocks such as increasing inflation or illness (Noerhidajati et al., 2021). Additionally, if some household members lose their jobs, they lose their income, and therefore they smooth consumption by borrowing (Kuk, 2017). On the other hand, another study examining the household indebtedness and financial wellbeing by Ordinary Least Square Regression confirmed that higher income causes greater indebtedness. Thus, it increases vulnerability through higher access to debt (Handayani et al., 2016).

Several studies pointed to the effect of macroeconomic factors important for household vulnerability. The most considerable macroeconomic factors affecting vulnerability are interest rates, level of unemployment, and house prices, but the level of indebtedness depends on the macroprudential policy. Regression analysis of the household debt, macroeconomic fundamentals, and household characteristics indicated that greater unemployment, interest rates, and increasing house prices reflect the higher vulnerability of households (Catherine et al., 2016; Pavelka \& Tomas, 2016). The positive effect of unemployment and interest rates on vulnerability is also confirmed by analysing determinants of household debt based on the autoregressive distributed lag modelling and Ordinary Least Square (Abid \& Shafiai, 2018; Azmin et al., 2019). The level of household indebtedness and vulnerability might depend on the country households live in and its policies. Some countries (Belgium, the Czech Republic, Denmark, Estonia, Finland, Italy, Luxembourg, the Netherlands, Sweden) provide a mortgage interest tax relief that allows homeowners to deduct their interest on a loan. Higher tax deduction increases the demand for debt (Bover et al., 2016). Many studies confirmed that mortgage interest tax relief encourages people to buy larger homes and commit to larger mortgages (Alpanda \& Zabairy, 2017; Gruber et al., 2017). In the case of the tax deduction abolition, there is an immediate reduction in investment in housing by around $6.00 \%$. As a result, it is subsequently reflected in indicators of household indebtedness and financial stability (Keightley, 2020). 
Moreover, various countries have set different limits on loan-to-value ratios (LTV). An increase in LTV leads to a higher demand for secured debt, mainly for young and low-income households, because they may finance their property almost entirely by debt (Barrios et al., 2019). Another study explains that households holding loans with a lower LTV are considered less vulnerable due to continued ability to repay existing loans even in a decline in property prices (Bilyk et al., 2017).

Related to the definition of household financial vulnerability, various measurements of vulnerability can be used. The most common indicator of vulnerability is the debt service-toincome ratio given by the share of obligated debt payments and disposable income (Ampudia et al., 2015). Authors of other studies use the debt-to-income ratio and debt-to-asset ratio to measure the financial vulnerability of households (Fessler et al., 2017; Leika \& Marchettini, 2017). These measures of financial vulnerability used various thresholds to define a household as vulnerable. For example, Terraneo (2018), and Fessler et al. (2017) set the threshold level for debt-to-asset ratio at $75 \%$, for debt-to-income ratio at three times and debt service-to-income ratio at $40 \%$. The authors argue that households with indicators above these values are not in default at present, but there is a greater probability of having difficulties in the future.

\section{Data Description}

Presented analysis used the Household Finance and Consumption Survey (HFCS) data, containing information on socio-demographic variables, assets, liabilities, income, consumption, and household financial situation and economic behaviour. It is conducted in the Eurozone member states from 2010/early 2011 every three years. HFCS is coordinated by the European Central Bank (ECB), and in each country, it is carried out by the National Central Bank. The respondent sample size was increasing in each wave: 62,000 households (15 countries) in HFCS $1 ; 84,600$ households (20 countries) in HFCS 2 ; and the total sample size of the HFCS data from the third wave were 91,200 households (22 countries) (European Central Bank, 2016b).

The dataset is based on methodological principles, ensuring the comparability of results in various European countries (European
Central Bank, 2016a). A specific methodological aspect of the data is the use of Bayesian-based multiple imputations that helps to tackle the issue of non-response. The imputation process results in five versions of data and helps to preserve the characteristics of the distribution and the relationships between different variables. Moreover, to ensure the sample's representativeness, HFCS used a set of population weights as well, and the sum of the estimation weights equals the total number of households in the country. The National Banks calibrated the weights based on the number of households with 1, 2, 3 or more members, the number of men and women, different age groups in each region, and distribution of the population according to the economic activity (European Central Bank, 2016b).

Specific limits of HFCS reflects its crosssectional basis, so the sample of interviewed households can differ across the waves. It is essential to take this feature into account mainly when interpreting changes in the characteristics of specific groups of households. Moreover, the HFCS sample does not have a panel structure as a whole. It should be highlighted that it is not feasible to draw any conclusions on the economic performance of the same households across the individual waves (European Central Bank, 2020). Every wave of the survey has a different country base as well. The list of countries that participated in the individual waves of the HFCS is attached in the Appendix (Tab. A1). The values of assets and liabilities are obtained by self-assessment, but they use supportive documentation such as account statements or tax returns. This step of data collection is considered a deliberate choice, given the goal of using the survey to study the behaviour of individual households (European Central Bank, 2021). Despite mentioned limitations of HFCS, it is the only harmonised set of data based on households' balance sheets which provide detailed household-level information on wealth for the entire household population across the EU countries (Fessler \& Schürz, 2018; Terraneo, 2018).

The approach to analyse the determinants of household financial vulnerability includes the following household characteristics:

Household vulnerability: To measure the household financial vulnerability, the ratio between total monthly debt payments and household gross monthly income was used. 
The greatest mean vulnerability of households in the HFCS with the value of $170.30 \%$ was recorded in the third wave. The mean vulnerability of households had decreased between the first and the second wave from $133.60 \%$ to $128.18 \%$. The median vulnerability was lower than the mean and was decreasing the whole analysed period, from $13.00 \%$ in the first wave to $12.30 \%$ in the second and $11.00 \%$ in the third wave.

Presence of the elderly: The variable presence of the elderly provides information about the number of household members aged 65 years or more living in one household. Most members older than 65 years living in one household were recorded in the first wave (5 members), while in the second and third wave, no more than five members aged 65 and more lived under the same roof.

Children: All dependent persons aged 0-15 and persons aged 16-24 do not work and always live with a parent - the most dependent children (13) living in one household in the first wave. The average number of dependent children was decreasing in all three waves. On the other hand, number of households without children increased from $65.91 \%$ in the first to $68.81 \%$ in the second and $70.22 \%$ in the third wave.

Education: Variable informs about the highest completed education of the reference person. HFCS uses Canberra ISCED classification, and in this study, six stages of ISCED classification are aggregated into four categories. The first category includes no formal/below ISCED 1 education and primary education, the second lower secondary and second stage of primary education. The third category obtains upper secondary and post-secondary education, while the fourth represents tertiary and higher education. In all three waves, the most reference persons have upper secondary education, while households without education had the smallest share.

Gender: It is a dummy variable equal to 1 if the reference person is men, otherwise $=0$. In all three waves, the share of men in a position of reference person was almost two times higher than the share of women.

Employment: Number of household members that are currently employed. The most significant share had households without any employed household members in all three waves. The mean number of employed household members was 0.97 in the first, 0.95 in the second, and 0.98 in the third wave, while the median number was equal to one in all three surveys.

Real assets: Real assets of households represents the value of total real assets, including the primary residence, vehicles, valuables, and business assets expressed in euros. The average value of a household's real assets was the highest in the first wave, $467,539.26$ euros. On the contrary, the lowest average value was $337,854.39$ euros recorded in the third wave.

Financial assets: Financial assets include the value of deposits, mutual funds, bonds, shares, and money owed to households expressed in euros. The average value of a household's financial assets was decreasing the whole three waves, from $119,535.63$ euros in the first to $98,999.30$ euros in the third wave.

Wealth: Variable wealth express total household assets minus total outstanding household liabilities in euros. The most significant average household wealth was in the second wave (425,714.74 euros). The lowest average wealth of households was recorded in the third wave, 208,208.40 euros. The lowest median wealth of households that participated in the HFCS was $114,597.60$ euros in the third wave.

Location: Dummy variable indicating whether the household lives in a country of Western Europe $=1$, otherwise $=0$.

To take into account the differences of individual countries from the macroeconomic point of view, the following variables representing different implemented macroprudential policies published by the European Commission (2019) were also included in the analysis:

Loan-to-value ratio: Variable representing the limit of the loan-to-value ratio of a given country. $\operatorname{LTV}=1$, if household lives in a country where the maximum LTV is in the range $0.60-0.80 ; \mathrm{LTV}=2$, if the maximum LTV is in the range 0.81-0.99, and LTV $=3$ if the maximum LTV is more than 0.99 .

Mortgages interest tax relief: Dummy variable that denotes the existence of tax relief on mortgage payments. The variable equals one if the household lives in a country where such an exemption exists, otherwise $=0$.

Descriptive statistic of variables is summarised in Tab. 1 and Tab. 2. All statistics were calculated using the HFCS database, survey weights, and five imputed datasets. 


\begin{tabular}{|c|c|c|c|c|c|}
\hline Variable & Minimum & Maximum & Mean & Median & Std. dev. \\
\hline \multicolumn{6}{|l|}{ Vulnerability } \\
\hline First wave & 0.00 & 545.16 & 1.34 & 0.13 & 46.07 \\
\hline Seconds wave & 0.00 & 678.00 & 2.28 & 0.12 & 48.13 \\
\hline Third wave & 0.00 & 471.00 & 1.70 & 0.11 & 45.32 \\
\hline \multicolumn{6}{|c|}{ Wealth (EUR thousand) } \\
\hline First wave & $-57,203.15$ & $401,119.66$ & 234.94 & 116.47 & 8.54 \\
\hline Seconds wave & $-3,850.00$ & $524,042.00$ & 425.71 & 136.66 & 310.10 \\
\hline Third wave & $-6,758.20$ & $369,417.85$ & 208.21 & 114.60 & 289.80 \\
\hline \multicolumn{6}{|c|}{ Real assets (EUR thousand) } \\
\hline First wave & 0.00 & $391,419.30$ & 467.54 & 198.56 & $2,630.06$ \\
\hline Seconds wave & 0.00 & $468,442.00$ & 355.60 & 150.50 & $2,346.41$ \\
\hline Third wave & 0.00 & $345,312.43$ & 337.85 & 141.42 & $1,913.96$ \\
\hline \multicolumn{6}{|c|}{ Financial assets (EUR thousand) } \\
\hline First wave & 0.00 & $101,139.66$ & 119.54 & 13.30 & 956.84 \\
\hline Seconds wave & 0.00 & $295,488.21$ & 108.29 & 9.92 & 137.82 \\
\hline Third wave & 0.00 & $192,392.51$ & 99.00 & 9.79 & $1,148.05$ \\
\hline \multicolumn{6}{|l|}{ Employment } \\
\hline First wave & 0.00 & 6.00 & 0.97 & 1.00 & 0.01 \\
\hline Seconds wave & 0.00 & 7.00 & 0.95 & 1.00 & 0.01 \\
\hline Third wave & 0.00 & 8.00 & 0.98 & 1.00 & 1.38 \\
\hline \multicolumn{6}{|l|}{ Children } \\
\hline First wave & 0.00 & 13.00 & 0.54 & 0.00 & 0.01 \\
\hline Seconds wave & 0.00 & 11.00 & 0.53 & 0.00 & 0.01 \\
\hline Third wave & 0.00 & 12.00 & 0.52 & 0.00 & 0.01 \\
\hline \multicolumn{6}{|l|}{ Elderly } \\
\hline First wave & 0.00 & 5.00 & 0.42 & 0.00 & 0.01 \\
\hline Seconds wave & 0.00 & 4.00 & 0.44 & 0.00 & 0.01 \\
\hline Third wave & 0.00 & 4.00 & 0.45 & 0.00 & 2.45 \\
\hline
\end{tabular}

Source: HFCS, own

\section{Methodology}

Determinants of household financial vulnerability were estimated following the ordinary least square (OLS) regression. OLS regression allows determining the relative influence of one or more predictors (explanatory) variables to the criterion value (explained variable) by estimating conditional mean functions. Additionally, estimated coefficients in the regression mean approach express the average change in the explained variable associated with a one-unit change in the related explanatory variable. The general equation of the OLS multiple regression model has the following form:

$$
Y_{i}=\beta_{0}+\beta_{1} X_{i, 1}+\beta_{2} X_{i, 2}+\ldots+\varepsilon_{i}
$$




\begin{tabular}{|c|c|c|c|}
\hline \multirow[t]{2}{*}{ Tab. 2: } & \multicolumn{3}{|c|}{$\begin{array}{l}\text { Descriptive statistic (\% share of household based on household } \\
\text { characteristics) }\end{array}$} \\
\hline & First wave & Second wave & Third wave \\
\hline \multicolumn{4}{|l|}{ Gender } \\
\hline Men & 68.76 & 62.39 & 61.65 \\
\hline Women & 31.24 & 37.61 & 38.35 \\
\hline \multicolumn{4}{|l|}{ Education } \\
\hline Null & 1.60 & 0.78 & 0.14 \\
\hline ISCED 1 & 19.25 & 14.61 & 13.42 \\
\hline ISCED 2 & 16.23 & 15.20 & 12.75 \\
\hline ISCED 3 & 34.38 & 39.82 & 42.18 \\
\hline ISCED 4 & 3.64 & 2.87 & 3.57 \\
\hline ISCED 5 & 22.70 & 24.69 & 25.81 \\
\hline ISCED 6 & 2.20 & 2.03 & 2.13 \\
\hline \multicolumn{4}{|l|}{ Employment } \\
\hline Null & 36.71 & 38.19 & 36.94 \\
\hline One & 33.46 & 32.80 & 33.33 \\
\hline Two & 26.24 & 25.49 & 25.83 \\
\hline Three & 2.97 & 2.95 & 3.04 \\
\hline Four & 0.57 & 0.56 & 0.73 \\
\hline Five and more & 0.05 & 0.01 & 0.13 \\
\hline \multicolumn{4}{|l|}{ Elderly } \\
\hline Null & 65.99 & 67.49 & 66.51 \\
\hline One & 20.40 & 21.66 & 22.01 \\
\hline Two & 10.81 & 10.72 & 11.37 \\
\hline Three & 1.02 & 0.12 & 0.10 \\
\hline Four and more & 1.78 & 0.01 & 0.01 \\
\hline \multicolumn{4}{|l|}{ Children } \\
\hline Null & 65.91 & 68.81 & 70.22 \\
\hline One & 15.81 & 15.12 & 13.65 \\
\hline Two & 12.68 & 12.50 & 11.75 \\
\hline Three & 3.17 & 3.07 & 3.36 \\
\hline Four & 0.60 & 0.71 & 0.77 \\
\hline Five and more & 1.83 & 0.25 & 0.25 \\
\hline
\end{tabular}

where:

$Y_{i}$ : explained variable, in case of our study it was the financial vulnerability represented by debt service-to-income ratio; $x_{1}, x_{2}, \ldots, x_{i}$ : explanatory variables, represent the household characteristics in an observation $i$; $i$ : the number of observations, $i=0,1,2, \ldots, N$; $\varepsilon$ : error term; 
$\beta_{0}$ : estimated $Y$-intercept;

$\beta_{j}$ : proxy the value of regression coefficient $j$ for $j=0,1,2, \ldots, K$.

The ordinary least squares estimator is obtained by minimizing the sum of squared residuals:

$$
\min _{\beta \in R^{k}}\left(\sum_{\in\left\{i: y \geq x_{i} \beta\right.} y_{i}-x_{i}^{\prime} \beta\right)^{2}
$$

OLS model was checked for competing key assumptions: multivariate normality, no autocorrelation, and homoscedasticity, and no correlation between explanatory variables using Jarque-Bera test, VIF factor, Durbin-Watson test, Breusch-Pagan test, and Goldfeld-Quandt test. Violation of some of these assumptions should lead to biased coefficient estimations. Heteroscedasticity and autocorrelationconsistent (HAC) estimators of the variancecovariance matrix helped solve this issue (Zeileis et al., 2004).

While the least-squares regression analysis does not give robust results in the presence of outliers and data should have skewness and kurtosis that matches a normal distribution, as an alternative, quantile regression was used (Nomatye \& Phiri, 2017; Rivero \& Sanroman, 2018; Hua \& Erreygers, 2019). The quantile regression approach can be applied even if the assumption of homoscedasticity is violated. For example, OLS regression considers the effect of explanatory on explained variables at the mean, but quantile regression considers this relationship at different quantiles (denoted by q) of the distribution of an explained variable (Koenker \& Bassett, 1978).

Quantile regression aims at estimating the conditional median (or other quantiles) of the response variable employing symmetric weights for the median (quantile $=0.5$ ) and asymmetric weights for other quantiles (e.g., 0.1, 0.2, ..., 0.9). Quantile regression estimates are obtained by minimising an asymmetrically weighted sum of absolute deviations (Waldmann, 2018).

Following Koenker and Bassett (1978), consider $\left(y_{i}, x_{i}\right) i=1, \ldots, N$ a random sample obtained from a population, where $x_{i}$ is a vector of explanatory variables and $y_{i}$ represents explained variable. Then the general equation of regression for a certain quantile $0<\theta<1$ is defined as the solution to the minimization problem:

$$
\begin{aligned}
& \min _{b \in R^{K}}\left[\sum_{t \in\left\{t: y_{t} \geq x_{t} b\right\}} \theta\left|y_{t}-x_{t} b\right|+\right. \\
& \left.+\sum_{t \in\left\{t: y_{t}<x_{t} b\right\}}(1-\theta)\left|y_{t}-x_{t} b\right|\right]
\end{aligned}
$$

Monetary values (wealth, income, assets, and debt) used in the presented study do not meet the statistical assumptions of research mainly due to skewed distributions often; therefore, the natural log and categorical transformations are used. However, when the natural log is not the most appropriate transformation, there are several cases, while it should not be taken for zero or negative values. The submitted paper used inverse hyperbolic sine transformation that can be expressed as (Friedline et al., 2014):

$$
\operatorname{ihs}(x)=\log \left(\sqrt{x^{2}+1+x}\right)
$$

where: $x$ is the variable of interest (wealth, asset, debt) and $i h s(x)$ is the transformed version of this variable.

The whole statistical computing analysis was executed in the $\mathrm{R}$ software environment (R Core Team, 2018) and took into account the weights and multiple imputations of the HFCS database.

\section{Research Results and Discussion}

The effect of household and household head characteristics on the level of household financial vulnerability in the selected European countries is reported in Tab. 3, Tab. 4, and Tab. 5 that display the results of OLS and quantile regression. The first column contains the OLS estimates, the second OLS estimates after application of heteroscedasticity and autocorrelation consistent (HAC) covariance matrix. The next columns show the results of quantile regression according to various quantiles. Grey shaded rows display estimates, while white italic rows are p-values (bold font indicates statistical significance). Moreover, scatterplot visualisation was used and presented in Fig. 1, Fig. 2, and Fig. 3. The $\mathrm{x}$-axis displays the quantiles, while the $y$-axis presents coefficients. The straight dotted line represents OLS estimates, and two straight dashed lines show OLS confidence intervals. 
Tab. 3: Results of OLS and quantile regression from the first wave of the HFCS

\begin{tabular}{|c|c|c|c|c|c|c|c|c|c|c|c|}
\hline Variable & OLS & OLS' & Q10 & Q20 & Q30 & Q40 & Q50 & Q60 & Q70 & Q80 & Q90 \\
\hline \multirow[t]{2}{*}{ Intercept } & 0.116 & 0.116 & -0.009 & -0.001 & 0.013 & 0.031 & 0.056 & 0.094 & 0.130 & 0.193 & 0.302 \\
\hline & 0.000 & 0.000 & 0.009 & 0.762 & 0.004 & 0.000 & 0.000 & 0.000 & 0.000 & 0.000 & 0.000 \\
\hline \multirow[t]{2}{*}{ MITR } & -0.029 & -0.029 & -0.025 & -0.036 & -0.035 & -0.042 & -0.044 & -0.044 & -0.046 & -0.046 & -0.047 \\
\hline & 0.000 & 0.001 & 0.000 & 0.000 & 0.000 & 0.000 & 0.000 & 0.000 & 0.000 & 0.000 & 0.002 \\
\hline \multirow[t]{2}{*}{ LTV } & 0.014 & 0.014 & 0.009 & 0.013 & 0.012 & 0.014 & 0.014 & 0.013 & 0.015 & 0.018 & 0.021 \\
\hline & 0.000 & 0.000 & 0.000 & 0.000 & 0.000 & 0.000 & 0.000 & 0.000 & 0.000 & 0.000 & 0.017 \\
\hline \multirow[t]{2}{*}{ Location } & -0.041 & -0.041 & -0.023 & -0.030 & -0.028 & -0.031 & -0.040 & -0.044 & -0.049 & -0.074 & -0.104 \\
\hline & 0.000 & 0.000 & 0.000 & 0.000 & 0.000 & 0.000 & 0.000 & 0.000 & 0.000 & 0.000 & 0.000 \\
\hline \multirow[t]{2}{*}{ Elderly } & -0.049 & -0.049 & -0.006 & -0.014 & -0.022 & -0.026 & -0.028 & -0.032 & -0.036 & -0.045 & -0.061 \\
\hline & 0.000 & 0.000 & 0.000 & 0.000 & 0.000 & 0.000 & 0.000 & 0.000 & 0.000 & 0.000 & 0.000 \\
\hline \multirow[t]{2}{*}{ Children } & 0.005 & 0.005 & 0.002 & 0.006 & 0.007 & 0.007 & 0.006 & 0.005 & 0.004 & 0.003 & 0.006 \\
\hline & 0.003 & 0.089 & 0.005 & 0.000 & 0.000 & 0.000 & 0.000 & 0.000 & 0.054 & 0.200 & 0.153 \\
\hline \multirow[t]{2}{*}{ Employment } & -0.034 & -0.034 & 0.000 & -0.002 & -0.006 & -0.010 & -0.014 & -0.020 & -0.027 & -0.032 & -0.052 \\
\hline & 0.000 & 0.000 & 0.830 & 0.220 & 0.000 & 0.000 & 0.000 & 0.000 & 0.000 & 0.000 & 0.000 \\
\hline \multirow[t]{2}{*}{ Gender } & -0.008 & -0.008 & 0.004 & 0.004 & 0.002 & 0.000 & -0.004 & -0.011 & -0.010 & -0.007 & -0.021 \\
\hline & 0.030 & 0.237 & 0.029 & 0.098 & 0.430 & 0.910 & 0.215 & 0.011 & 0.030 & 0.228 & 0.124 \\
\hline \multirow[t]{2}{*}{ Education } & -0.005 & -0.005 & -0.001 & -0.001 & -0.000 & -0.000 & -0.001 & -0.002 & -0.003 & -0.008 & -0.011 \\
\hline & 0.000 & 0.005 & 0.162 & 0.595 & 0.998 & 0.666 & 0.583 & 0.148 & 0.026 & 0.000 & 0.003 \\
\hline \multirow[t]{2}{*}{ Wealth (ihs) } & -0.027 & -0.027 & -0.006 & -0.012 & -0.016 & -0.017 & -0.019 & -0.021 & -0.022 & -0.025 & -0.028 \\
\hline & 0.000 & 0.000 & 0.000 & 0.360 & 0.000 & 0.120 & 0.000 & 0.011 & 0.000 & 0.000 & 0.000 \\
\hline \multirow{2}{*}{$\begin{array}{l}\text { Real assets } \\
\text { (ihs) }\end{array}$} & 0.058 & 0.058 & 0.011 & 0.024 & 0.034 & 0.039 & 0.044 & 0.049 & 0.054 & 0.058 & 0.066 \\
\hline & 0.000 & 0.000 & 0.101 & 0.321 & 0.000 & 0.000 & 0.000 & 0.000 & 0.000 & 0.000 & 0.000 \\
\hline \multirow{2}{*}{$\begin{array}{l}\text { Financial } \\
\text { assets (ihs) }\end{array}$} & 0.058 & 0.058 & 0.000 & -0.003 & -0.006 & -0.009 & -0.008 & -0.009 & -0.009 & -0.006 & -0.003 \\
\hline & 0.000 & 0.003 & 0.887 & 0.015 & 0.000 & 0.000 & 0.000 & 0.000 & 0.000 & 0.002 & 0.500 \\
\hline
\end{tabular}

Source: own

On the other hand, confidence intervals for quantile regression are displayed by a grey area, and a dashed-dotted line presents quantile regression estimates in the middle. While scatterplot visualisation showed a significant deviation of quantile regression estimates from the OLS one, it highlighted the appropriateness of using the quantile regression approach.

OLS and quantile regression results from the first wave displayed in Tab. 4 and Fig. 1 confirmed that the importance of various factors differs across various deciles.
A decrease in household financial vulnerability is associated mainly with financial and macroeconomic factors such as employment, financial assets, the level of wealth, or mortgage interest tax relief. Variable employment recorded a negative value of the regression coefficient that was decreasing toward the ninth decile. The most significant decline in financial vulnerability associated with more household members in employment along the whole distribution was recorded in this wave. However, during the first wave 


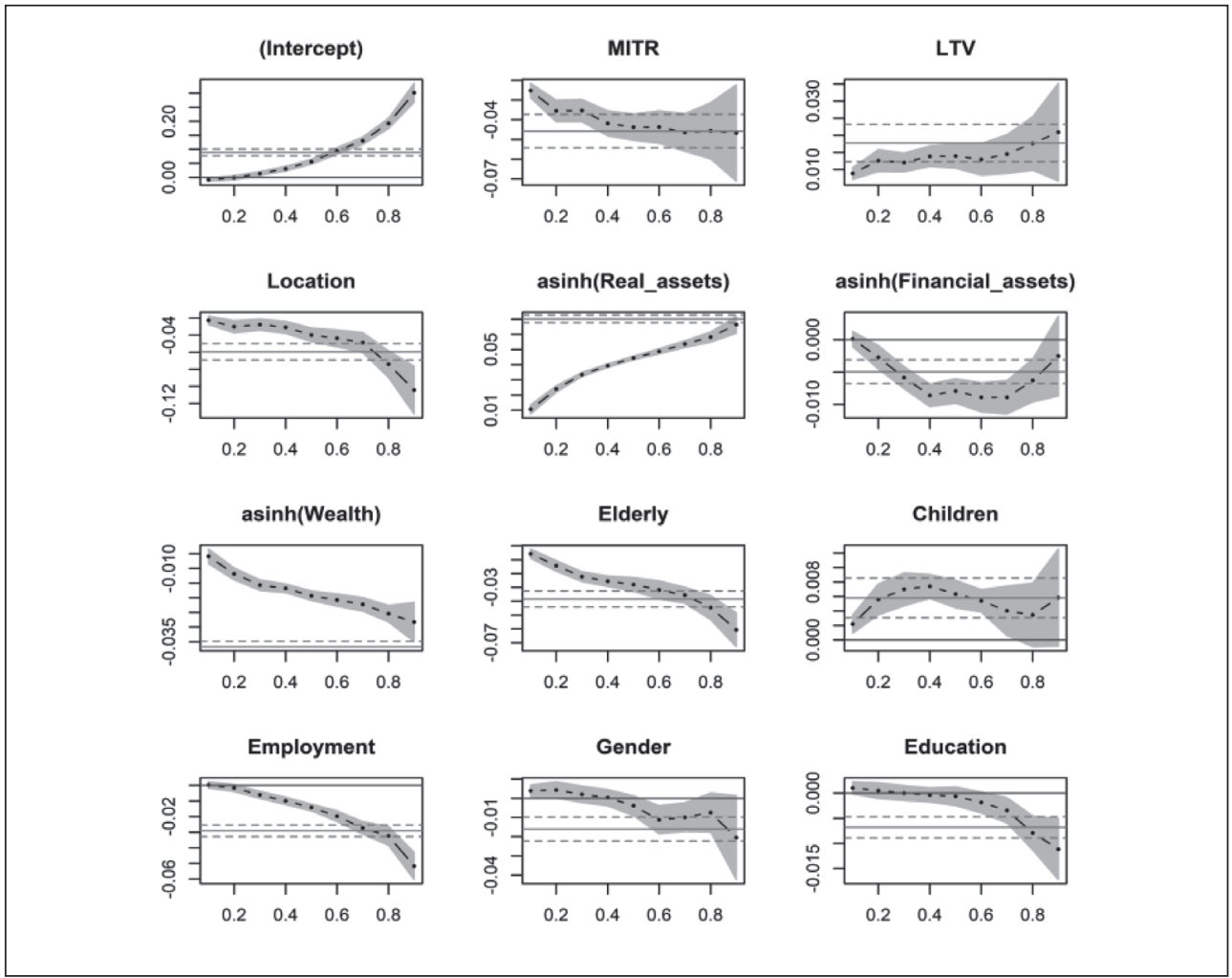

Source: FCS, own

of HFCS, the period was influenced by the Great Recession of 2008, associated with an increase in inflation, interest rates, government debt, and unemployment rate. The inflation and unemployment rate was increasing from 2009 to 2011 in most European countries.

Moreover, as a consequence of the global financial crisis, employment income stagnated. The high inflation rate triggered a sharp rise in household debt and, in connection with increasing unemployment and stagnating income, led to greater household vulnerability (Claessens et al., 2014). This result is closely linked to the studies of Noerhidajati et al. (2021) and Kuk (2017), suggesting that higher income and more employed household members allow individuals to absorb adverse shocks such as increasing inflation. On the other hand, results contradict to study explaining that higher employment and income increase vulnerability through higher access to debt (Handayani et al., 2016). However, statistical significance differs across various deciles. The number of employed household members was statistically significant at a significance level $p<0.001$ in all deciles only in the second wave.

Results of the analysis seem to agree with Noerhidajati et al. (2021); Sachin et al. (2018), explaining that an increase in household quickly monetisable assets (financial assets) and wealth has resulted in a decrease in financial vulnerability. Financial assets could be used as a quick source of income mainly in times of unexpected situations and/or worse economic conditions and therefore are an essential factor in the financial position of households. However, 
while the level of wealth recorded statistical significance $p<0.001$ along all deciles, the statistical significance of the financial assets was not confirmed in the first and ninth deciles.

Additionally, countries providing mortgage interest tax relief to owners of residential real estates recorded lower vulnerability of households than countries without tax deductions. A decrease is statistically significant along with the whole debt service-to-income distribution. Reducing mortgage interest tax relief increases the financing costs mainly of credit-constrained households. As a result, households reduce demand for loans, and financial vulnerability decreases (Burgert et al., 2016). It contradicts the studies explaining that mortgage interest tax relief supports households to take a loan and increases willingness to commit to larger mortgages (Bover et al., 2016; Alpanda \& Zabairy, 2017; Jensen \& Kleven, 2017). Macroeconomic dummy variable Location recorded negative regression coefficient values in all deciles, indicating the lower financial vulnerability of households in Western European countries after controlling all variables $(p<0.001)$.

Other factors whose increase is associated with a decrease of vulnerability are sociodemographic factors such as the number of household members aged 65 and more and educational attainment. The regression coefficient of the variable Elderly recorded a negative value lowering towards the ninth decile. It means that several elderlies are associated with a more significant decrease in household vulnerability, mainly at the top of debt service-to-income ratio distribution. The result was significant at a significance level $p<0.001$. It is in line with the works of (Danziger et al., 1982; Yusof et al., 2015; Haq et al., 2018) that confirmed the negative effect of age on debt accumulation. This is because older household members usually spend less compared to the young ones setting up their households.

Moreover, older household members do not cover their consumption by debt and prefer assets accumulation and emergency fund creation essential to overcome unexpected shocks. It is also evident in the studies analysing the level of debt service-toincome ratio according to various household characteristics, such as European Central Bank (2016a), and Azzopardi et al. (2019). The average indebtedness of European households decreased with the age of the reference person. The highest level of debt was recorded in households with a reference person aged 35-44 in all three waves.

Variable education was statistically significant only for the upper three deciles, recording the lowest value of regression coefficients. It suggests that level of education is essential mainly for more vulnerable households represented by a more significant share of debt service on income. A higher level of education is associated with a better understanding of the various financial products and a more responsible repayment of existing loans. Households with lower levels of education are more interested in the demand for unsecured loans offered by non-banking institutions and therefore are exposed to financial vulnerability (Yusof et al., 2015). Our results are also consistent with the studies explaining that the level of education affects the ability to manage financial resources and the level of savings that helps to overcome unexpected situations (Brounen et al., 2016; Noerhidajati et al., 2021).

On the other hand, more children, higher value of real assets, and loan-to-value ratio are associated with increased financial vulnerability. In line with (Togba, 2012; Hua \& Erreygers, 2019), results confirmed the importance of the number of children associated with more household members for financial vulnerability and the whole distribution of vulnerability indicator except the ninth decile. Furthermore, households with more members recorded the greater vulnerability measured by the debt service-to-income ratio (European Central Bank, 2016a). More dependent children increase household vulnerability mainly through higher care-taking expenses, lower savings and often lead to taking the loan for children's education.

The last socio-demographic factor analysed concerning household financial vulnerability was the dummy variable Gender. Quantile regression analysis did not provide specific results. As it can be seen, male-headed households are less vulnerable, but mainly in the upper deciles. It could be explained by men's more significant responsibility in debt repayment (Ntsalaze \& Ikhide, 2016). Our results contradict the findings that women are more risk-averse and prefer investments in safer, lower-yield assets that lower their financial vulnerability (Killewald et al., 2018). 
Although financial vulnerability is referred to as poverty of assets or lack of wealth accumulation, a higher level of assets and wealth does not necessarily mean higher financial stability. At the same time, it could be used as loan collateral that encourages people to commit to more significant loans. Real assets showed a strong positive effect on vulnerability in the whole sample, and the regression coefficient increased towards the ninth decile. It indicated a more significant increase in household vulnerability caused by a rise in the value of financial assets, especially in the ninth decile. Real assets of households consist mainly of properties financed by mortgage loans. Mortgages are considered to be a major factor of increasing indebtedness associated with greater vulnerability. In addition, real assets can be used as collateral for loans that threaten financial stability (Andrews et al., 2011; Haq et al., 2018).

The macroeconomic variable loan-to-value ratio recorded a positive value of regression coefficient and statistical significance and the whole vulnerability distribution. Thus, it indicates that increasing the maximum loan-to-value

Tab. 4: Results of OLS and quantile regression from the second wave of the HFCS

\begin{tabular}{|c|c|c|c|c|c|c|c|c|c|c|c|}
\hline Variable & OLS & OLS' & Q10 & Q20 & Q30 & Q40 & Q50 & Q60 & Q70 & Q80 & Q90 \\
\hline \multirow[t]{2}{*}{ Intercept } & 0.128 & 0.128 & -0.025 & -0.024 & -0.011 & 0.007 & 0.032 & 0.060 & 0.100 & 0.162 & 0.303 \\
\hline & 0.000 & 0.000 & 0.000 & 0.000 & 0.002 & 0.285 & 0.000 & 0.000 & 0.000 & 0.000 & 0.000 \\
\hline \multirow[t]{2}{*}{ MITR } & 0.024 & 0.024 & -0.010 & -0.024 & -0.032 & -0.034 & -0.041 & -0.044 & -0.046 & -0.045 & -0.025 \\
\hline & 0.000 & 0.000 & 0.000 & 0.000 & 0.000 & 0.000 & 0.000 & 0.000 & 0.000 & 0.000 & 0.001 \\
\hline \multirow[t]{2}{*}{ LTV } & 0.006 & 0.006 & 0.001 & -0.003 & -0.006 & -0.006 & -0.007 & -0.008 & -0.005 & -0.003 & -0.001 \\
\hline & 0.047 & 0.421 & 0.860 & 0.007 & 0.000 & 0.001 & 0.000 & 0.000 & 0.016 & 0.321 & 0.920 \\
\hline \multirow[t]{2}{*}{ Location } & -0.001 & -0.001 & 0.045 & 0.007 & 0.009 & 0.010 & 0.012 & 0.014 & 0.010 & -0.005 & -0.029 \\
\hline & 0.764 & 0.822 & 0.003 & 0.000 & 0.000 & 0.000 & 0.000 & 0.000 & 0.012 & 0.281 & 0.000 \\
\hline \multirow[t]{2}{*}{ Elderly } & -0.079 & -0.079 & -0.004 & -0.014 & -0.021 & -0.026 & -0.032 & -0.037 & -0.043 & -0.053 & -0.071 \\
\hline & 0.000 & 0.000 & 0.000 & 0.000 & 0.000 & 0.000 & 0.000 & 0.000 & 0.000 & 0.000 & 0.000 \\
\hline \multirow[t]{2}{*}{ Children } & 0.001 & 0.001 & 0.002 & 0.004 & 0.005 & 0.005 & 0.006 & 0.006 & 0.005 & 0.004 & 0.000 \\
\hline & 0.510 & 0.816 & 0.064 & 0.001 & 0.000 & 0.000 & 0.000 & 0.000 & 0.005 & 0.006 & 0.899 \\
\hline \multirow[t]{2}{*}{ Employment } & -0.008 & -0.008 & -0.002 & -0.003 & -0.004 & -0.005 & -0.006 & -0.007 & -0.008 & -0.009 & -0.014 \\
\hline & 0.000 & 0.000 & 0.000 & 0.000 & 0.000 & 0.000 & 0.000 & 0.000 & 0.000 & 0.000 & 0.000 \\
\hline \multirow[t]{2}{*}{ Gender } & -0.050 & -0.049 & 0.002 & 0.000 & -0.003 & -0.006 & -0.011 & -0.016 & -0.024 & -0.034 & -0.063 \\
\hline & 0.000 & 0.885 & 0.009 & 0.967 & 0.001 & 0.000 & 0.000 & 0.000 & 0.000 & 0.000 & 0.000 \\
\hline \multirow[t]{2}{*}{ Education } & -0.001 & -0.001 & -0.001 & -0.002 & -0.003 & -0.001 & -0.001 & -0.000 & -0.004 & -0.005 & -0.010 \\
\hline & 0.772 & 0.000 & 0.474 & 0.273 & 0.035 & 0.445 & 0.794 & 0.985 & 0.241 & 0.263 & 0.133 \\
\hline \multirow[t]{2}{*}{ Wealth (ins) } & -0.010 & -0.010 & -0.001 & -0.002 & -0.001 & -0.000 & -0.002 & -0.003 & -0.005 & -0.008 & -0.019 \\
\hline & 0.000 & 0.014 & 0.048 & 0.001 & 0.033 & 0.003 & 0.031 & 0.050 & 0.004 & 0.000 & 0.000 \\
\hline \multirow{2}{*}{$\begin{array}{l}\text { Real assets } \\
\text { (ihs) }\end{array}$} & 0.043 & 0.043 & 0.005 & 0.014 & 0.021 & 0.026 & 0.030 & 0.035 & 0.039 & 0.043 & 0.058 \\
\hline & 0.000 & 0.000 & 0.000 & 0.000 & 0.000 & 0.000 & 0.000 & 0.000 & 0.000 & 0.000 & 0.000 \\
\hline \multirow{2}{*}{$\begin{array}{l}\text { Financial } \\
\text { assets (ihs) }\end{array}$} & -0.014 & -0.014 & 0.000 & -0.004 & -0.008 & -0.010 & -0.012 & -0.015 & -0.016 & -0.016 & -0.015 \\
\hline & 0.000 & 0.000 & 0.043 & 0.000 & 0.000 & 0.000 & 0.000 & 0.000 & 0.000 & 0.000 & 0.000 \\
\hline
\end{tabular}


ratio is related to an increase in vulnerability. It is also evident in the papers of André (2016) and Barrios et al. (2019), explaining that an increase in LTV leads to a higher demand for secured debt. Mainly for young and low-income households because they may finance their property almost entirely by debt. Moreover, households holding loans with a lower LTV are considered less vulnerable to financial shocks mainly due to continued ability to repay existing loans even in the case of a decline in property prices (Bilyk et al., 2017).

The analysis applied to the second wave of HFCS presented in Tab. 4 and Fig. 2 shows similar results.

While the number of older household members, employment, wealth, and financial assets are associated with the decrease of the household vulnerability indicator, the number of children and real assets reflect in higher debt service-to-income ratio. A significant difference was recorded in LTV restrictions associated with a decrease of vulnerability in each decile except for the first one. However, in the second wave, five more countries (Poland, Latvia, Ireland, Hungary, and Estonia) recorded a higher share of vulnerable on totally indebted households than the average of all countries that participated in the HFCS. Compared to 2010, LTV restrictions changed only in six countries. While maximum LTV increased in the Netherland, Belgium, Latvia, Portugal, and Slovakia, Lithuania's maximum value of the LTV ratio decreased. This result from the second wave contradicts the studies suggesting that higher LTV threatens the household financial vulnerability (André, 2016; Bilyk et al., 2017; Barrios et al., 2019). New participated countries

\section{Fig. 2: Results of quantile regression from the second wave of the HFCS}

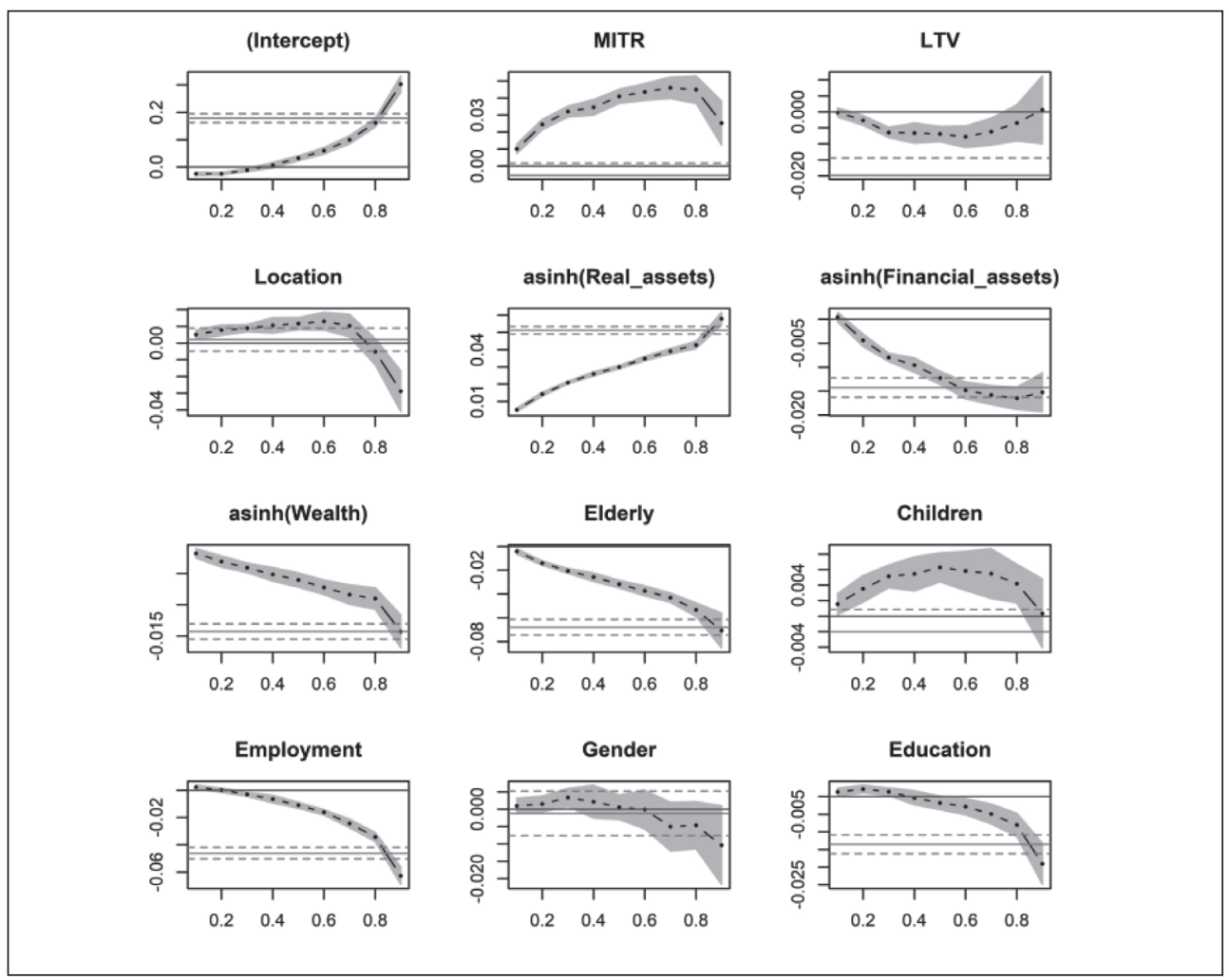


in HFCS did not provide mortgage interest tax relief, so similar to the results from the first wave, households living in countries where a tax deduction is provided are less vulnerable.

Compared to the first wave, results also indicated that households from Western Europe are more vulnerable in the lower six deciles of debt service-to-income distribution. A difference can also be seen in the variable gender that reports a positive value only for the lower two deciles. It indicates that maleheaded households are less vulnerable across the most vulnerability indicator distribution after controlling all variables.
Considering the household financial vulnerability, it should be mentioned that financial position and vulnerability reflect the overall economic environment. The period between the first and second wave of the HFCS survey is characterised by financial turbulences, leading to a rise in the pricing of sovereign risk and a markedly increase in sovereign bonds. The crisis led to higher bank lending rates (European Central Bank, 2016b) and was associated with an abrupt decline in real estate prices. Along with lower income and higher unemployment, this unexpected situation seriously jeopardised the ability of households

Tab. 5: Results of OLS and quantile regression from the third wave of the HFCS

\begin{tabular}{|c|c|c|c|c|c|c|c|c|c|c|c|}
\hline Variable & OLS & OLS' & Q10 & Q20 & Q30 & Q40 & Q50 & Q60 & Q70 & Q80 & Q90 \\
\hline \multirow[t]{2}{*}{ Intercept } & 0.071 & .071 & 0.036 & 0.044 & -0.026 & -0.014 & 0.002 & 0.023 & 0.052 & 0.113 & 0.236 \\
\hline & 0.000 & 0.034 & 0.000 & 0.000 & 0.000 & 0.000 & 0.687 & 0.001 & 0.000 & 0.000 & 0.000 \\
\hline \multirow[t]{2}{*}{ MITR } & 0.040 & 0.040 & 0.008 & 0.015 & 0.013 & 0.017 & 0.020 & 0.023 & 0.030 & 0.032 & 0.034 \\
\hline & 0.000 & 0.000 & 0.000 & 0.000 & 0.000 & 0.000 & 0.000 & 0.000 & 0.000 & 0.000 & 0.000 \\
\hline \multirow[t]{2}{*}{ LTV } & 0.027 & 0.027 & -0.011 & -0.018 & -0.020 & -0.024 & -0.027 & -0.032 & -0.036 & -0.043 & -0.044 \\
\hline & 0.000 & 0.003 & 0.000 & 0.000 & 0.000 & 0.000 & 0.000 & 0.000 & 0.000 & 0.000 & 0.000 \\
\hline \multirow[t]{2}{*}{ Location } & 0.003 & 0.003 & 0.012 & 0.010 & 0.009 & 0.005 & 0.002 & -0.004 & -0.010 & -0.018 & -0.034 \\
\hline & 0.594 & 0.720 & 0.000 & 0.000 & 0.000 & 0.011 & 0.492 & 0.217 & 0.004 & 0.000 & 0.000 \\
\hline \multirow[t]{2}{*}{ Elderly } & -0.074 & -0.074 & -0.007 & -0.016 & -0.024 & -0.028 & -0.033 & -0.037 & -0.041 & -0.047 & -0.061 \\
\hline & 0.000 & 0.000 & 0.000 & 0.000 & 0.000 & 0.000 & 0.000 & 0.000 & 0.000 & 0.000 & 0.000 \\
\hline \multirow[t]{2}{*}{ Children } & 0.012 & 0.012 & 0.001 & 0.002 & 0.002 & 0.002 & 0.001 & -0.000 & 0.002 & 0.003 & -0.007 \\
\hline & 0.000 & 0.024 & 0.115 & 0.047 & 0.091 & 0.092 & 0.495 & 0.733 & 0.266 & 0.085 & 0.680 \\
\hline \multirow[t]{2}{*}{ Employment } & -0.021 & -0.021 & -0.002 & -0.003 & -0.003 & -0.005 & -0.006 & -0.006 & -0.008 & -0.010 & -0.031 \\
\hline & 0.000 & 0.000 & 0.094 & 0.029 & 0.170 & 0.009 & 0.006 & 0.030 & 0.028 & 0.010 & 0.003 \\
\hline \multirow[t]{2}{*}{ Gender } & 0.010 & -0.010 & 0.001 & -0.000 & -0.001 & -0.001 & 0.000 & -0.003 & -0.004 & -0.008 & -0.016 \\
\hline & 0.000 & 0.087 & 0.188 & 0.962 & 0.530 & 0.298 & 0.852 & 0.114 & 0.051 & 0.002 & 0.003 \\
\hline \multirow[t]{2}{*}{ Education } & -0.023 & -0.023 & -0.006 & -0.010 & -0.011 & -0.013 & -0.014 & -0.016 & -0.017 & -0.018 & -0.021 \\
\hline & 0.001 & 0.118 & 0.000 & 0.000 & 0.000 & 0.000 & 0.000 & 0.000 & 0.000 & 0.000 & 0.000 \\
\hline \multirow[t]{2}{*}{ Wealth (ihs) } & -0.049 & -0.049 & -0.000 & -0.001 & -0.005 & -0.008 & -0.014 & -0.018 & -0.022 & -0.032 & -0.051 \\
\hline & 0.000 & 0.000 & 0.000 & 0.020 & 0.000 & 0.000 & 0.000 & 0.000 & 0.000 & 0.000 & 0.000 \\
\hline \multirow{2}{*}{$\begin{array}{l}\text { Real assets } \\
\text { (ins) }\end{array}$} & 0.062 & 0.062 & 0.013 & 0.024 & 0.029 & 0.035 & 0.039 & 0.044 & 0.047 & 0.052 & 0.063 \\
\hline & 0.000 & 0.000 & 0.000 & 0.000 & 0.000 & 0.000 & 0.000 & 0.000 & 0.000 & 0.000 & 0.000 \\
\hline \multirow{2}{*}{$\begin{array}{l}\text { Financial } \\
\text { assets (ihs) }\end{array}$} & -0.009 & -0.009 & 0.001 & -0.001 & -0.003 & -0.005 & -0.007 & -0.007 & -0.009 & -0.011 & -0.013 \\
\hline & 0.000 & 0.001 & 0.001 & 0.052 & 0.000 & 0.000 & 0.000 & 0.000 & 0.000 & 0.000 & 0.000 \\
\hline
\end{tabular}


to cope with existing financial commitments (European Central Bank, 2013). House prices decline lowered the net wealth of households relative to their debt. At the same time, debt payments swelled in reaction to inflation and depreciation.

As a consequence of the global financial crisis, many European households lost financial stability and had to cope with vulnerability (Claessens et al., 2014). Thus, the economic environment and essential changes in the value of real estate and household net wealth significantly affected the vulnerability of households in the second wave of the survey. Our results indicate that wealth, financial, and real assets are statistically significant in each decile of vulnerability distribution compared to the first wave. Another statistically significant determinant across the whole distribution of debt service-to-income ratio is mortgage interest tax relief, the number of elderlies, and employment.

The last third wave of the HFCS reported in Tab. 5 and Fig. 3 did not significantly differ from the previous two waves.

In the period between the year of the second (2014) and third (2017) survey, the gradual economic recovery associated with the steadily declining unemployment rate and lowering costs of household debt could be observed. Concerning this, the third wave highlighted the heterogeneous developments in total liabilities and assets of households. In this period, the most indebted European households could feel an easing of their financial pressure mainly due to income and asset prices rising due to economic recovery (European Central Bank, 2020).

\section{Fig. 3: Results of quantile regression from the third wave of the HFCS}

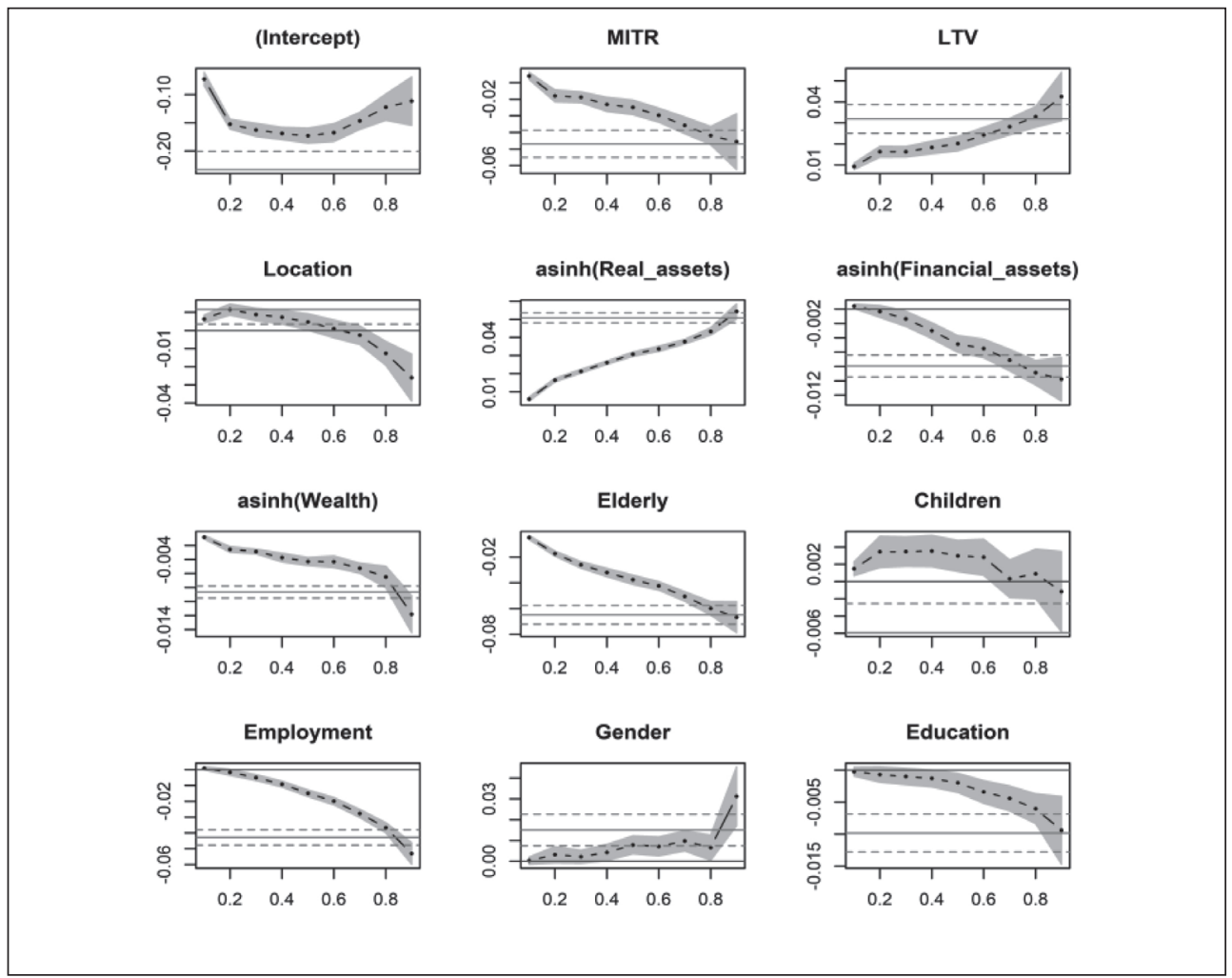


As it can be seen, the impact of household, household-head characteristics, financial, and macroeconomic determinants generally remained unchanged in all three waves except for mortgage interest tax relief, LTV restrictions, and dummy variables Location and Gender.

A variable representing the existence of mortgage interest tax relief showed the most considerable difference. While in the first two waves of the HFCS survey were households from countries with mortgage interest tax relief less indebted, tax deduction was associated with increased vulnerability in the last wave. Although the list of countries (Belgium, Estonia, Finland, Italy, Luxembourg, the Netherlands) providing this type of tax deduction did not change between 2014 and 2017, household demand for mortgages increased. Thus, while mortgage interest tax relief encourages people to buy larger homes and commit to larger mortgages (Alpanda \& Zabairy, 2017; Gruber et al., 2017), it threatens household financial stability.

The HFCS third wave results also show that only male-headed households from the first decile of debt service-to-income distribution are more vulnerable after controlling all variables. According to the results of analysis applied on the data from the last wave, households from Western European countries are less vulnerable in the case of the upper four deciles.

The difference was recorded in the statistical significance of analysed variables as well. Compared to the previous two waves, results confirm that mortgage interest tax relief, the number of elderlies, and the value of real assets are statistically significant factors. Moreover, the loan-to-value ratio and financial assets are also statistically significant in the third wave of HFCS.

\section{Conclusions}

In the current economic situation, households have a challenging role while considering their expectations of living standards and financial decisions. Household economic behaviour, over-indebtedness, and financial vulnerability have an impact on the financial markets and are precursors of crisis as well. It resulted in a growing interest in analysing the financial behaviour, risk profile, and stability of households. New data surveys such as HFCS have opened a broad field for investigating household indebtedness and allows authorities to take private household characteristics into account.

The empirical research of this paper focused on the potential drivers of household financial vulnerability in euro area households. By using all three waves of HFCS obtained from the European Central Bank, OLS and quantile regression estimation procedures were conducted to consider the effect of household, household-head, and countryspecific characteristics on the level of household vulnerability. To take into account the skewness of monetary values, hyperbolic sine transformation was used.

In response to the research questions, it can be stated that only the number of household members aged 65 and more and the level of wealth were statistically significant socio-demographic factors across the whole vulnerability distribution in all three waves. More household members aged 65+ and greater value of household wealth were associated with the decrease of household financial fragility indicator. A more significant difference in results was observed in the case of variables representing implemented macroprudential policies. In the first wave, the greater LTV has associated with an increase in the debt serviceto-income ratio. Households from countries with the existence of mortgage interest tax relief reported lower financial vulnerability. Results from the third wave showed that greater LTV leads to lower vulnerability, while tax deduction expects higher vulnerability of households. What exactly explains the difference in the results is an open question that deserves to be explored further.

Other explanatory variables did not report statistical significance across the whole distribution of vulnerability. However, most of the explained variables recorded the same effect on household financial vulnerability indicators across its whole distribution in all three waves. Results indicated that the number of children and the value of real assets were the only variables that positively affected the vulnerability in all Household Finance and Consumption Survey observations. On the other hand, the effect of wealth, financial assets, education, and employment was negative in all observations of all waves.

However, this study has some limitations. For example, specific features of the HFCS database, such as new countries participated 
in each wave or differences in the methodology, could lead to biased results between individual waves, and it should be taken into consideration. Therefore, for future research, we recommend extending the analysis to individual countries.

The submitted study contributes to the existing literature in several ways. Firstly, household-level data (HFCS) allowed detailed analysis of household financial vulnerability and household and household-head characteristics. Furthermore, the application of country-specific variables enabled the consideration of the different countries and their implemented policies that could affect the level of vulnerability. Secondly, while most of the studies analysing the determinants of financial stability used data from one wave of the HFCS survey, it does not allow to consider the different economic situation that due to the global financial crisis occurred between the first and second wave of the HFCS survey. Quantile regression applied individually to each wave thus allows not only to compare the results and fill this gap, but also to contribute to the existing literature. Moreover, using the quantile regression approach considered that factors influencing the level of household vulnerability could differ in individual quantiles of household vulnerability distribution.

Acknowledgements: This paper used the data from the Eurosystem Household Finance and Consumption Survey. The European Central Bank is not responsible for the results interpreted in this research paper. The presented paper is a partially output from the Grant GAAA 5-5/2020 "Family business in regions".

\section{References}

Abid, A., \& Shafiai, M. H. M. (2018). Determinants of Household Financial Vulnerability in Malaysia and Its Effect on Low-Income Groups. Journal of Emerging Economies \& Islamic Research, 6(1), 32-43. https://doi.org/10.24191/jeeir.v6i1.8772

Alpanda, S., \& Zubairy, S. (2017). Addressing Household Indebtedness: Monetary, Fiscal or Macroprudential Policy? European Economic Review, 92, 47-73. https://doi.org/10.1016/j. euroecorev.2016.11.004

Ampudia, M., Vlokhoven, H. A., \& Żochowski, D. (2016). Financial Fragility of Euro Area Households. Journal of Financial Stability, 27, 250-261. https://doi.org/10.1016/j. jfs.2016.02.003
André, C. (2016). Household Debt in OECD Countries: Stylised Facts and Policy Issues (Economic Department Working Papers No. 1277). Paris: OECD Publishing. https://doi. org/10.1787/5jm3xgtkk1f2-en

Andrews, D., Sánchez, A. C., \& Johanson, A. (2011). Housing Markets and Structural Policies in OECD Countries (Economics Department Working Papers, No. 836). Paris: OECD Publishing. https://doi. org/10.1787/5kgk8t2k9vf3-en

Azmin, N. M.A., Zaidi, W. N. W., \& Mohamad, Z. (2019). The Determinants that Influence Household Debt Case in Malaysia. KnE Social Sciences, 1215-1226. Retrieved from https:// knepublishing.com/index.php/KnE-Social/ article/view/4278/8786\#info/contributor_1

Azzopardi, D., Fareed, F., Lenain, P., \& Sutherland, D. (2019). Assessing Household Financial Vulnerability: Empirical evidence from the US using machine learning (Economic Survey of the United States: Key Research Findings). Paris: OECD Publishing. https://doi. org/10.1787/75c63aa1-en

Bi, L., \& Montalto, C. P. (2006): Emergency Funds and the Alternative Forms of Saving. Financial Services Review, 13(2), 93-109.

Bilyk, O., Ueberfeldt, A., \& Xu, Y. (2017). Analysis of Household Vulnerabilities Using Loan-Level Mortgage Data (Financial System Review 2017/11). Canada: Bank of Canada. Retrieved April 9, 2021, from https://www. bankofcanada.ca/wp-content/uploads/2017/11/ fsr-november2017-bilyk.pdf

Barrios, S., Denis, C., Ivaškaitè-Tamošiūnè, V., Reut, A., \& Torres, E. V. (2019). Housing Taxation: A New Database for Europe (JRC Working Paper on Taxation and Structural Reforms No 08/2019). Sevilla: European Commission. Retrieved January 13, 2021, from https://ec.europa.eu/jrc/sites/jrcsh/files/ jrc118277.pdf

Beer, C. M., \& Schurz, M. (2007). Characteristics of Household Debt in Austria: Does Household Debt Pose a Threat to Financial Stability? (Monetary Policy and the Economy Q2/07). Austria: Austrian National Bank.

Bover, O., Casado, J. M., Costa, S., Caju, P. D., McCarthy, Y., Sierminska, E., Tzamourani, P., Villanueva, E., \& Zavadil, T. (2016). The Distribution of Debt across Euro-Area countries: The Role of Individual Characteristics, Institutions, and Credit Conditions. International Journal of Central Banking, 12(2), 71-129. 
Brounen, D., Koedijk, K., \& Pownall, R. (2016). Household Financial Planning and Savings Behaviour. Journal of International Money and Finance, 69, 95-107. https://doi. org/10.1016/j.jimonfin.2016.06.011

Burgert, M., D'Souza, P., \& Vermeulen, G. (2016). House Prices and Indebtedness in Sweden: A Model-based Assessment of Policy Options (Economic Brief 021). Luxembourg: Publications Office of the European Union. Retrieved April 9, 2021, from https://ec.europa. eu/info/sites/info/files/file_import/eb021_en_2.pdf

Catherine, S. F. H., Yusof, J. M., \& Mainal, S. (2016). Household Debt, Macroeconomic Fundamentals and Household Characteristics in Asian Developed and Developing Countries. The Social Sciences, 11(18), 4358-4362. https:// doi.org/10.36478/sscience.2016.4358.4362

Claessens, S., Kose, A., Laeven, L., \& Valencia, F. (2014). Financial Crises: Causes, Consequences, and Policy Responses. Washington, DC: IMF. Retrieved April 9, 2021, from https://www.elibrary.imf.org/doc/IMF071/ 20264-9781475543407/20264-9781475543407/ Other_formats/Source_PDF/20264 9781484324295.pdf?redirect=true

Danziger, S., Van Der Gaag, J., Smolensky, E., \& Taussig, M. K. (1982). The Life-Cycle Hypothesis and the Consumption Behavior of the Elderly. Journal of Post Keynesian Economics, 5(2), 208-227. https://doi.org/10.1 080/01603477.1982.11489357

Daud, S. N. M., Marzuki, A., Ahmad, N., \& Kefeli, Z. (2019). Financial Vulnerability and Its Determinants: Survey Evidence from Malaysian Households. Emerging Markets Finance and Trade, 55(9), 1991-2003. https://doi.org/10.10 80/1540496X.2018.1511421

Demertzis, M., Domínguez-Jiménez, M., \& Lusardi, A. (2020). The Financial Fragility of European Households in Time of COVID-19 (Policy Contribution No 15). Belgium: Bruegel. Retrieved April 15, 2021, from http://aei.pitt. edu/103258/1/PC-15-2020-final.pdf

European Central Bank. (2013). The Eurosystem Household Finance and Consumption Survey, Results from the Second Wave (ECB Statistics Paper, No. 2). Frankfurt am Main: ECB. Retrieved January 13, 2021 , from https://www.ecb.europa.eu/pub/pdf/other/ ecbsp2en.pdf?2180f869d12ccc366869c941 9b3da32e

European Central Bank. (2016a). The Eurosystem Household Finance and
Consumption Survey, Results from the Second Wave (ECB Statistics Paper Series, No 18). Frankfurt am Main: ECB. Retrieved January 13, 2021, from https://www.econstor.eu/ bitstream/10419/154653/1/ecbsp18.pdf

European Central Bank. (2016b). The Household Finance and Consumption Survey: Methodological Report for the Second Wave (ECB Statistics Paper, No 17). Frankfurt am Main: ECB. Retrieved January 13, 2021, from https://www.ecb. europa.eu/pub/pdf/scpsps/ecbsp17.en.pdf

European Central Bank. (2020). The Eurosystem Household Finance and Consumption Survey, Results from the 2017 Wave (ECB Statistics Paper Series, No 36). Frankfurt am Main: ECB. Retrieved January 13, 2021, from https://www.ecb.europa.eu/pub/pdf/ scpsps/ecb.sps36 0245ed80c7.en.pdf

European Central Bank. (2021). Household Finance and Consumption Survey: About the Survey. Frankfurt am Main: ECB. Retrieved April 10, 2021, from https://www.ecb.europa. eu/pub/economic-research/research-networks/ $\mathrm{html} /$ researcher_hfcn-faq.cs.html

Eurostat. (2019). Gross Debt-to-Income Ratio of Households. Luxembourg: Eurostat. Retrieved January 13, 2021, from http:// appsso.eurostat.ec.europa.eu/nui/show. do?dataset=tec00104\&lang=en

Eurostat. (2021). Financial balance sheets. Luxembourg: Eurostat. Retrieved April 15, 2021 , from https://ec.europa.eu/eurostat/databrowser/ view/nasa_10_f_bs/default/table?lang=en

Fessler, P., List, M., \& Messner, T. (2017). How Financially Vulnerable Are CESEE Households? An Austrian Perspective on its Neighbours (Focus on European Economic Integration, Q2/17). Vienna: National Bank of Austria. Retrieved April 9, 2021, from https:// www.oenb.at/dam/jcr:66356a63-b720-42728f11-f51879e91386/feei_2017_q2_studies_ fessler_list_messner.pdf

Fessler, P., \& Schürz, M. (2018). Private Wealth across European Countries: The Role of Income, Inheritance and the Welfare State. Journal of Human Development and Capabilities, 19(4), 521-549. https://doi.org/10 .1080/19452829.2018.1507422

Friedline, T., Masa, R. D., \& Chowa, G. A. N. (2014). Transforming Wealth: Using the Inverse Hyperbolic Sine (IHS) and Splines to Predict Youth's Math Achievement. Social Science Research, 49, 264-287. https://doi. org/10.1016/j.ssresearch.2014.08.018 
Grejcz, K., \& Żółkiewski, Z. (2017). Household Wealth in Poland: The Results of a New Survey of Household Finance. Bank i Kredyt, 48(3), 295-326.

Gruber, J., Jensen, A., \& Kleven, H. (2017). Do People Respond to the Mortgage Interest Deduction? Evidence from Denmark (NBER Working Paper 23600). Cambridge: MA: National Bureau of Economic Research. Retrieved January 13, 2021, from https://www. nber.org/system/files/working_papers/w23600/ w23600.pdf

Handayani, D., Salamah, U., \& Yusacc, R. N. (2016). Indebtedness and Subjective Financial Welfare of Households in Indonesia. Economy and Finance Indonesia, 62(2), 78-87. http://efi. ui.ac.id/index.php/efi/article/view/549/566

Haq, W., Ismail, N. A., Satar, N. M., \& Watson, D. (2018). Household Debt in Different Age Cohorts: A Multilevel Study. Cogent Economics \& Finance, 6(1), 45. https://doi.org /10.1080/23322039.2018.1455406

Hua, T. X., \& Erreygers, G. (2019). Applying Quantile Regression to Determine the Effects of Household Characteristics on Household Savings Rates in Vietnam. Journal of Asian Business and Economic Studies, 27(2), 175-193. https://doi.org/10.1108/ JABES-06-2019-0053

International Monetary Fund. (2020). Household Debt, Loans and Debt Securities, Percent of GDP. Washington, DC: IMF. Retrieved January 13, 2021, from https://www. imf.org/external/datamapper/HH_LS@GDD/ USA?zoom=USA\&highlight=USA

Keightley, M. P. (2020). An Economic Analysis of the Mortgage Interest Tax Deduction (CRS Report No. R46429). Washington, DC: Congressional Research Service. Retrieved January 13, 2021, from https://fas.org/sgp/crs/ misc/R46429.pdf

Killewald, A., Pfeffer, F. T., \& Schachner, J. N. (2018). Wealth Inequality and Accumulation. Annual Review of Sociology, 43, 379-404. https://doi.org/10.1146/annurevsoc-060116-053331

Koenker, R., \& Bassett, G. (1978). Regressions Quantiles. Econometrica, 46(1), 33-50. https://doi.org/10.2307/1913643

Kukk, M. (2017). How Does Household Debt Affect Financial Asset Holdings? Evidence from Euro Area Countries. Studies in Economics and Finance, 34(2), 194-212. https://doi. org/10.1108/sef-02-2016-0031
Lee, M. P., \& Sabri, M. F. (2017). Review of Financial Vulnerability Studies. Archives of Business Research, 5(2), 127-134. https://doi. org/10.14738/abr.52.2784

Leika, M., \& Marchettini, D. (2017). A Generalized Framework for the Assessment of Household Financial Vulnerability (IMF Working Paper WP/17/228). Washington, DC: IMF. Retrieved April 4, 2021, from https://www.imf. org/en/Publications/WP/Issues/2017/11/07/AGeneralized-Framework-for-the-Assessmentof-Household-Financial-Vulnerability-45297

Midões, C., \& Seré, M. (2020). Living with Reduced Income: an Analysis of Household Financial Vulnerability under COVID-19 (Working Paper No 20/08). Antwerp: Centrum voor Sociaal Beleid - Herman Deleeck. Retrieved April 4, 2021, from https://medialibrary. uantwerpen.be/files/57001/33536a0e-e1b148a6-b755-811bf32a8ea3.pdf

Modigliani, F. (1986). The Life Cycle Hypothesis of Saving, the Demand for Wealth and the Supply of Capital. Social Research: An International Quarterly, 33(2), 160-217.

Ntsalaze, L., \& Ikhide, S. (2016). Household Over-indebtedness: Understanding its Extent and Characteristics of those Affected. Journal of Social Sciences, 48(1-2), 79-93. https://doi. org/10.1080/09718923.2016.11893573

Noerhidajati, S., Purwoko, A. B., Werdaningtyas, H., Kamil, A. I., \& Dartanto, T. (2021). Household Financial Vulnerability in Indonesia: Measurement and Determinants. Economic Modelling, 96, 433-444. https://doi. org/10.1016/j.econmod.2020.03.028

Nölke, A. (2016). Economic Causes of the Eurozone Crisis: The Analytical Contribution of Comparative Capitalism. Socio-Economic Review, 14(1), 141-161. https://doi. org $/ 10.1093 / \mathrm{ser} / \mathrm{mwv} 031$

Nomatye, A., \& Phiri, A. (2017). Investigating the Macroeconomic Determinants of Household Debt in South Africa (MPRA Paper No. 83303). Munich: Munich Personal RePEc Archive. Retrieved January 21, 2021, from https:// mpra.ub.uni-muenchen.de/83303/1/MPRA_ paper_83303.pdf

Pavelka, T., \& Löster, T. (2016). The Development of Unemployment in the European Union's Labour Market Due to the Recent Economic Crisis, Using Cluster Analysis. In M. H. Bilgin, H. Danis, E. Demir, \& U. Can (Eds.), Business Challenges in the Changing Economic Landscape (Vol. 1, pp. 323-337). 
Cham: Springer. https://doi.org/10.1007/978-3319-22596-8_23

Rahim, H. A. (2011). Factors Contributing to Financial Stability of Urban and Rural Families. Pertanika Journal of Social Science and Humanities, 19(1), 99-112.

$\mathrm{R}$ Core Team. (2018). R: Language and Environment for Statistical Computing. Vienna: $\mathrm{R}$ Foundation for Statistical Computing. Retrieved January 13, 2021, from https:// www.R-project.org

Sachin, B. S., Rajashekar, V., \& Ramesh, B. (2018). Festival Spending Pattern: Its Impact on Financial Vulnerability of Rural Households. Social Work Foot Print, 7(5), 48-57.

Rivero, J. I., \& Sanroman, G. (2020). Households Indebtedness: The Role of Income and Business Ownership in a Small Emerging Country (Working Paper No. 20). Montevideo, Ukraine: Udelar FCS-DE. Retrieved January 21, 2021, from https://www.colibri.udelar.edu. uy/jspui/bitstream/20.500.12008/26107/1/ DT\%20E\%202020-08.pdf

Statista. (2021). Total Financial Assets of U.S. Households 2000-2020. Financial balance sheets. New York, NY: Statista. Retrieved April 15, 2021, from https://www. statista.com/statistics/188542/financial-assetsof-households-in-the-us/

Terraneo, M. (2018). Households' Financial Vulnerability in Southern Europe. Journal of Economic Studies, 45(3), 521-542. https://doi. org/10.1108/JES-08-2016-0162

Togba, E. L. (2012). Microfinance and Households Access to Credit: Evidence from Côte d'Ivoire. Structural Change and Economic Dynamics, 23(4), 473-486. https://doi. org/10.1016/j.strueco.2012.08.002
Treanor, M. (2016). The Effects of Financial Vulnerability and Mothers' Emotional Distress on Child Social, Emotional and Behavioural Well-Being: A Structural Equation Model. Sociology, 50(4), 673-694. https://doi. org/10.1177/0038038515570144

Waldmann, E. (2018). Quantile regression: A Short Story on How and Why. Statistical Modelling, 18(3-4), 203-218. https://doi. org/10.1177/1471082x18759142

Walugembe, P., Wamala, R., Misinde, C., \& Larok, R. (2019). Child and Household SocialEconomic Vulnerability: Determinants Transition from Moderate and Critical Vulnerability Levels in Rural Uganda. Childhood Vulnerability Journal, 2(29), 29-50. https://doi.org/10.1007/ s41255-020-00011-y

Wildauer, R. (2016). Determinants of US Household Debt: New Evidence from the SCF (Working Papers PKWP 1608). Greenwich: Post-Keynesian Economics Society. Retrieved January 13, 2021, from http://www. postkeynesian.net/downloads/working-papers/ PKWP1608.pdf

Yildirimm, T. (2015). Did the Euro Trigger the European Debt Crises? Journal of International Studies, 8(2), 43-51. https://doi. org/10.14254/2071-8330.2015/8-2/4

Yusof, S. A., Rokis, R., \& Wan Jusoh, W. J. (2015). Financial Fragility of Urban Households in Malaysia. Jurnal Ekonomi Malaysia, 49(1), 15-24. https://doi.org/10.17576/JEM-20154901-02

Zeileis, A., Lumley, T., Berger, S., \& Graham, N. (2004). Econometric Computing with $\mathrm{HC}$ and HAC Covariance Matrix Estimators. Journal of Statistical Software, 11(10), 17. https://doi. org/10.18637/jss.v011.i10 


\section{Appendix}

\section{Tab. A1: Countries participated in the HFCS}

\begin{tabular}{|c|c|c|}
\hline First wave (HFCS 2010) & Second wave (HFCS 2014) & Third wave (HFCS 2017) \\
\hline $\begin{array}{l}\text { Austria, Belgium, Cyprus, } \\
\text { Germany, Spain, Finland, } \\
\text { France, Greece, Italy, Malta, } \\
\text { Luxembourg, the Netherlands, } \\
\text { Portugal, Slovenia, Slovakia }\end{array}$ & $\begin{array}{l}\text { Austria, Belgium, Cyprus, } \\
\text { Germany, Spain, Finland, } \\
\text { France, Greece, Italy, Malta, } \\
\text { Luxembourg, the Netherlands, } \\
\text { Portugal, Slovenia, Slovakia, } \\
\text { Poland, Ireland, Hungary, } \\
\text { Estonia, Lithuania }\end{array}$ & $\begin{array}{l}\text { Austria, Belgium, Cyprus, } \\
\text { Germany, Spain, Finland, } \\
\text { France, Greece, Italy, Malta, } \\
\text { Luxembourg, the Netherlands, } \\
\text { Portugal, Slovenia, Slovakia, } \\
\text { Poland, Ireland, Hungary, } \\
\text { Estonia, Lithuania, Croatia, } \\
\text { Latvia }\end{array}$ \\
\hline
\end{tabular}

Note: Countries written in bold participated in the survey for the first time. 